\title{
FIRE RESISTANCE FOR THIN-WEBBED CONCRETE AND MASONRY ELEMENTS
}

\author{
György L. Balázs, Éva Lublóy \\ Deptartement of Construction Materials and Technologies, Budapest University of Techn. and Economics, Hungary
}

\begin{abstract}
Deterioration of material characteristics and structural performance highly depends on constituents and temperature history. Material composition can also highly influence structural behaviour of elements. Thickness of web can be critical for high temperatures. The same situation is for interjoist elements (concrete or brick) between precast roof girders.

First part of our study was to improve fire resistance by structural elements with a typical thin web. Our experimental study included fire tests on various concrete mixes and fire tests of the girder with simultaneous application of load. Second part of our study was to summarize the result of real fire cases for girder-slab systems with concrete or brick interjoists.
\end{abstract}

Keywords: fire, thin webbed elements, slab-girder system, interjoist, concrete spalling, material deterioration

\section{INTRODUCTION}

An extensive review of the fire effects can be found for a variety of $\mathrm{R} / \mathrm{C}$ and $\mathrm{P} / \mathrm{C}$ members has been published a few years ago by Annerel and Taerwe (2009). In this study the results of a $2 \mathrm{~h}$ fire test on a sub-assembly of a high-rise building is presented. The structure included pretensioned girders, hollow-core slabs, roof slabs, columns and masonry walls (Fig. 1).

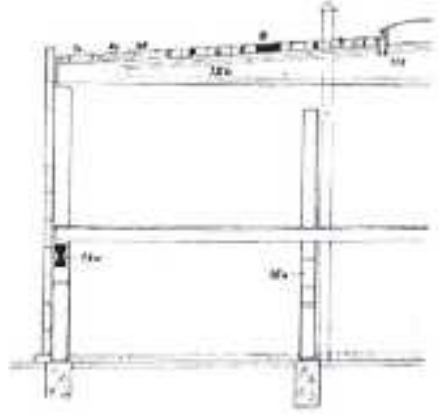

The structure of building

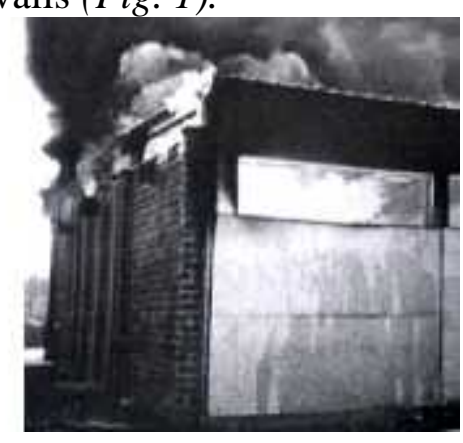

b) The fire test

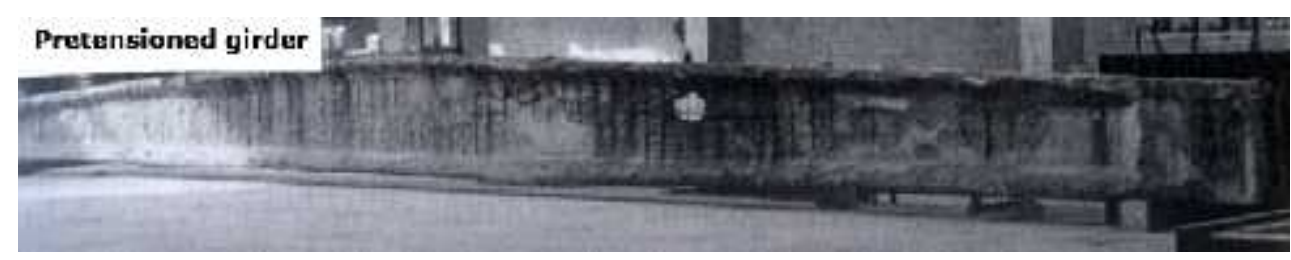

c) The fire damaged girder

Fig. 1 Sub-assembly of a high-rise building after a $2 \mathrm{~h}$ fire test (Annerel and Taerwe, 2009)

The concrete of the presented roof girder had an ordinary mix with calcareous pebbles and gravel for coarse and medium aggregates, and river sand for fine aggregates. The top flange was heavily damaged over most of the span, as shown by one strand, that is visible (the cover was gone) and by the longitudinal cracks, that are located at about $100 \mathrm{~mm}$ from the extrados (top face). 
Several stirrups are also visible, after the explosion of the cover, that was lost roughly over the entire span. Spalling depths of up to $80 \mathrm{~mm}$ were measured (Annerel and Taerwe, 2009).

In case of hollow-core slabs the voids make the heat transfer rather complex and modelling the heat transfer is difficult as heat is transmitted from the bottom surface to the top surface of the voids via radiation and convection (Fig. 2).

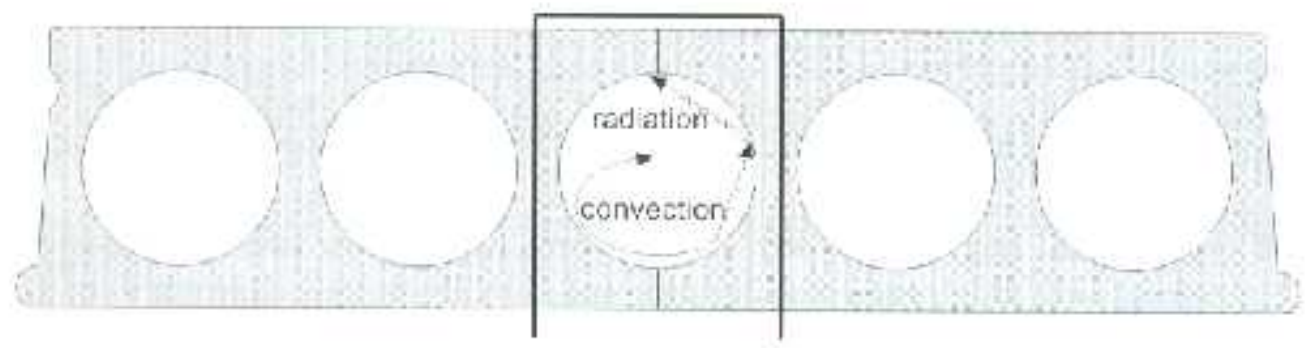

Fig. 2 The hollow-core slab is an example for a concrete member with longitudinal internal holes (Fellinger, 2004)

The same problem takes place by girder-slab systems. The damage process of interjoists between precast girders in fire is faster compared to the damage of girders. In case of girder-slab systems the voids of the interjoist make heat transfer, therefore, the damage of interjoists in fire is faster than the damage of the girders. The fire resistance of girder-slab systems is different from traditional slabs.

\section{TESTING OF THIN WEBBED GIRDERS}

\subsection{Tests on the materials}

A few fire tests indicated the inadequacy to fire resistance of a typical thin-webbed $(\mathrm{t}=60 \mathrm{~mm})$, prestressed pretensioned roof girder. Self compacting concrete (Mix l) included $460 \mathrm{~kg} / \mathrm{m}^{3}$ cement $($ CEM I $42.5 \mathrm{~N}), 165 \mathrm{~kg} / \mathrm{m}^{3}$ water, $1679 \mathrm{~kg} / \mathrm{m}^{3}$ siliceous aggregate, $130 \mathrm{~kg} / \mathrm{m}^{3}$ limestone filler and $3.8 \mathrm{~kg} / \mathrm{m}^{3}$ super plasticizer. This mix and the small thickness of the web resulted in the spalling of the concrete cover.

In order to decrease the temperature sensitivity of the concrete and to improve the fire resistance of the girder without changing the geometry, we directed our efforts to the optimization of mix properties. Therefore, the concrete mix design was modified in the following way (Table 1):

- by changing the filler from limestone (Blaine-fineness $660 \mathrm{~kg} / \mathrm{m}^{2}$ ) to slag (Blaine-fineness $460 \mathrm{~kg} / \mathrm{m}^{2}$ ) and

- by adding polypropylene fibres (monofilament polypropylene fibres, $1=12 \mathrm{~mm}, \varnothing=0.032 \mathrm{~mm}$ ) to the mix.

This resulted mixes: Mix 2, Mix 3 and Mix 4 (Table 1).

Table 1 Test parameters (all other constituents were the same as for the reference mix)

\begin{tabular}{|c|c|c|c|c|}
\hline Concrete mix & Filler & $\begin{array}{c}\text { PP fibres, } \\
\mathrm{kg} / \mathrm{m}^{3}\end{array}$ & $\begin{array}{c}\text { Material test } \\
20^{\circ} \mathrm{C}, 600^{\circ} \mathrm{C}, \\
800^{\circ} \mathrm{C}\end{array}$ & $\begin{array}{c}\text { Beam test } \\
(\text { Scale 1:1 })\end{array}$ \\
\hline $\begin{array}{c}\text { Mix 1 } \\
\text { (reference) }\end{array}$ & limestone & 0 & + & Beam 1 \\
\hline Mix 2 & limestone & 1 & + & Beam 2 \\
\hline Mix 3 & limestone & 2 & + & - \\
\hline Mix 4 & slag & 1 & + & Beam 3 \\
\hline
\end{tabular}


The tests on concrete samples were carried at the Department of Construction Materials and Engineering Geology of Budapest University of Technology and Economics. The cube samples ( side $=150 \mathrm{~mm}$ ) were kept for 2 hours at $600{ }^{\circ} \mathrm{C}$ or $800{ }^{\circ} \mathrm{C}$, and later were cooled down to room temperature. We have observed the highest relative residual compressive strength by changing the filling material from limestone to slag and including also $1 \mathrm{~kg} / \mathrm{m}^{3}$ polypropylene fibres, subjected to $800{ }^{\circ} \mathrm{C}$ (Fig. 3).

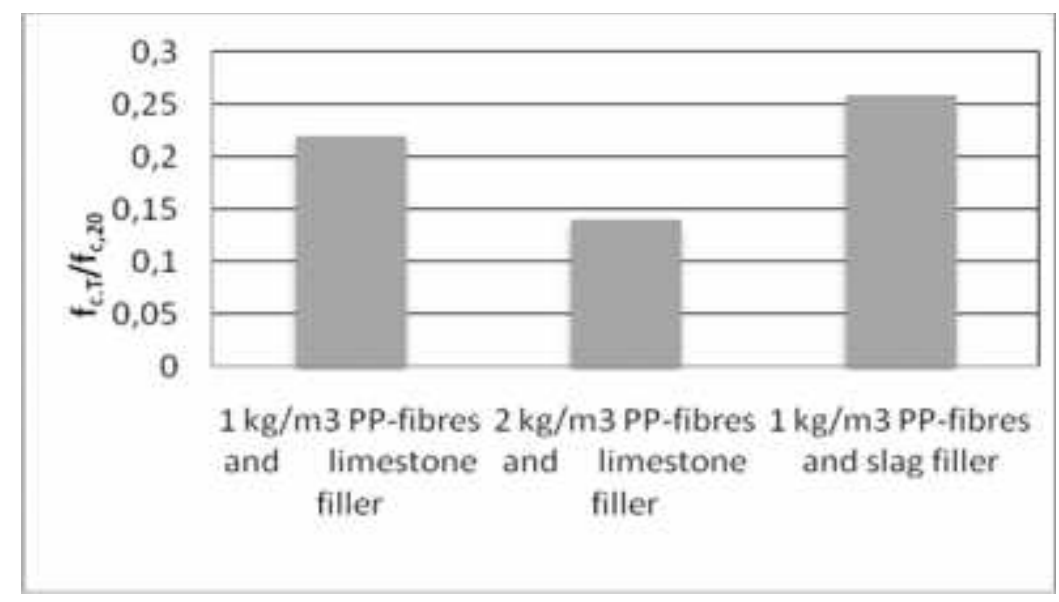

Fig. 3 Normalized values of the residual compressive strength after heating up to $800{ }^{\circ} \mathrm{C}$ (each point is the average of 3 measurements). The compressive strength at $20^{\circ} \mathrm{C}$ (no heating) has been used as normalizing factor

\subsection{Tests on beam specimens}

Fire tests were carried out on beam specimens made of three different concretes. Test parameters are indicated in Table 1 for Mix 1, Mix 3 and Mix 4. The tests were performed in the Fire Laboratory of ÉMI Non-profit Ltd. The heating process was monitored and controlled by the thermocouples of the furnace, and the temperature-time curve was very close to the Standard Fire curve (ISO 834).

After the usual curing in a controlled environment (for 28 days) and before being heated, the specimens were stored for one months under ordinary environmental conditions until hygral equilibrium was reached.

Three specimens were tested in this project, i.e. as many as the mixes (Mixes 1, 3 and 4).

All specimens have the same T-type section; their length is $3.4 \mathrm{~m}$; the prestressing force amounts to $130 \mathrm{kN}$; the type of the concrete is C40/50-XC2-16-F4 (XC is the corrosion induced by carbonation; $16 \mathrm{~mm}$ is the maximal aggregate size; F4 is the class of consistency measured by flow table test), while the type of reinforcing bars is S500B and the type of the prestressing reinforcement is FP-100/1770-R2 (EN 10138). The length of specimen was limited by the size of furnace, but we tested the real cross section with limited load. The cause of this solution was to follow the real behaviour of this cross section in fire.

Each beam was firstly loaded with two forces $(350 \mathrm{kN}$ each) that were kept constant throughout the heating process.

Beam No. 1 (Mix 1 = reference mix) failed in 12 minutes after the complete spalling of the concrete of the web (Fig. 4).

Beam No. 2 (Mix 2 including $1 \mathrm{~kg} / \mathrm{m}^{3}$ of polypropylene fibres and limestone filler) failed in 44 minutes in shear (no spalling of the web).

Beam No. 3 (Mix 4 including $1 \mathrm{~kg} / \mathrm{m}^{3}$ polypropylene fibres and a slag-based filler) failed in 71 minutes in shear (no spalling of the web, Fig. 5). 
The test results in terms of fire resistance are presented in Fig. 6, where the improvement due to the combined effects of slag-based filler and pp fibres is remarkable indeed (Balázs, Lublóy, Mezei, 2010).

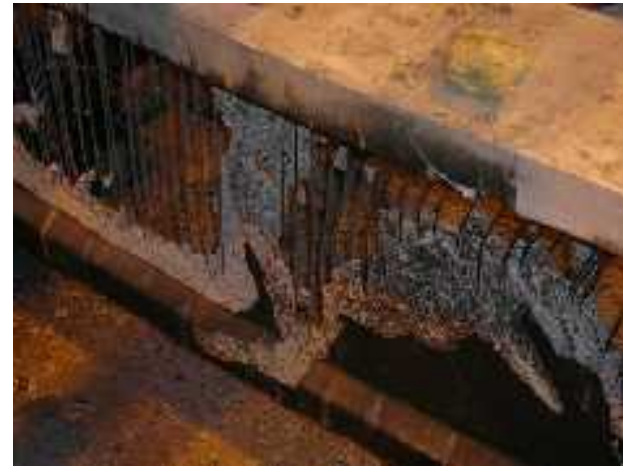

Fig. 4 Beam No. 1 (ref. Mix 1) after failure due to web destruction

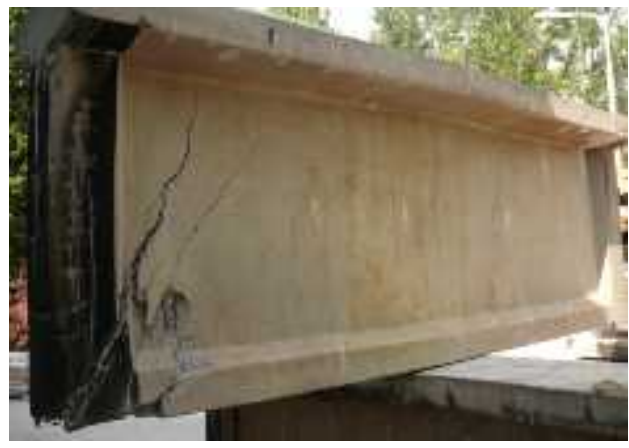

Fig.5 Beam No. 3 (Mix 4) after the web failure in shear

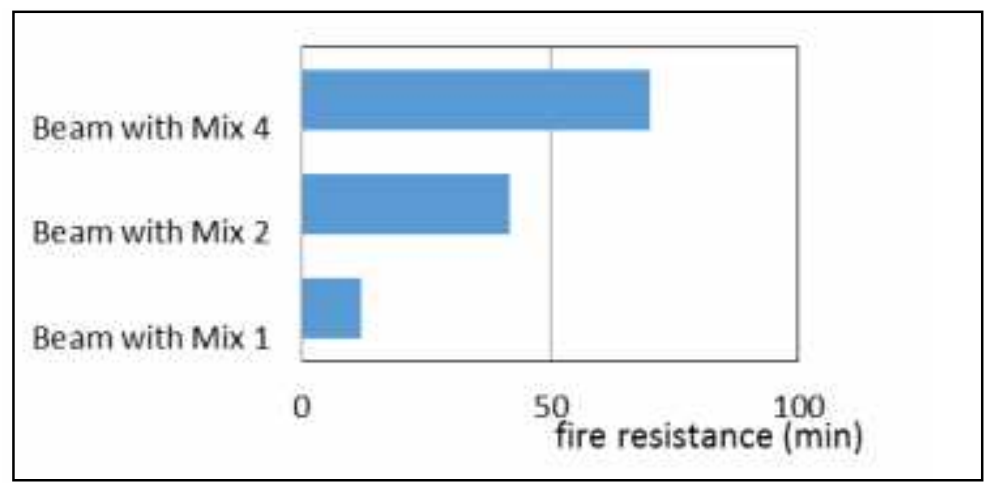

Fig. 6 Fire resistance of the three beam specimens tested in this project

\section{RESULTS OF REAL FIRE ON CONCRETE OR BRICK INTERJOISTS}

\subsection{Concrete interjoist}

A family house went up in flames on 1. April 2010. The slab consisted of pretensioned E type girders and concrete interjoists were made without reinforcement (Fig. 7). The axis-distance of E type girders were $60 \mathrm{~cm}$. The type of girders were E7-54. The height of interjoists was $19 \mathrm{~cm}$. The type of interjoists were EB 60/19. The span of girders were $5.40 \mathrm{~m}$.
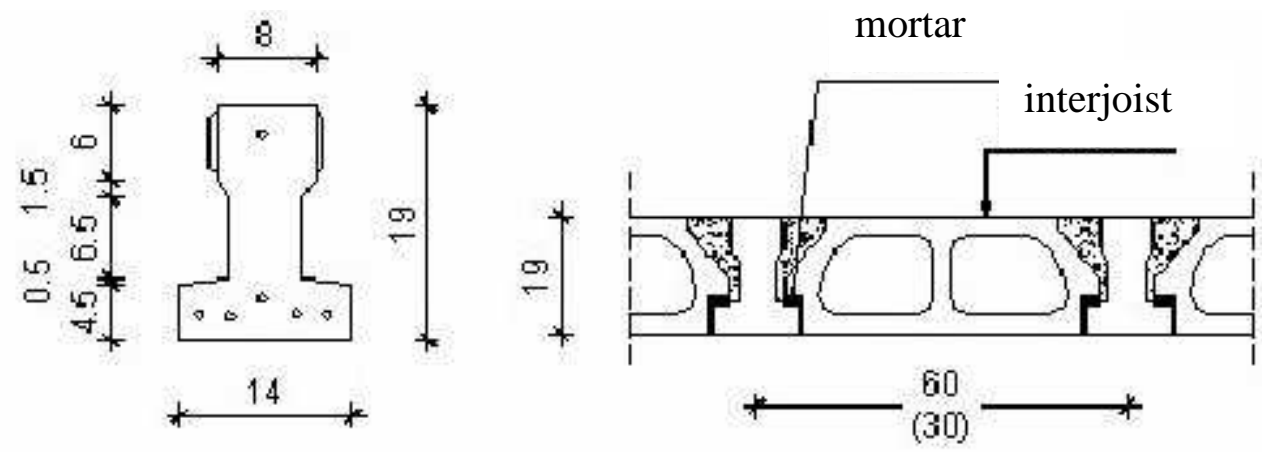

Fig. 7 The girder-slab system with concrete interjoists (http://dutker.hu) (sizes in $\mathrm{cm}$ )

Due to the fire the slab was damaged (Fig. 8). Some of the pretensioned E-girders were cracked. The concrete became red-coloured, indicating that the maximum temperature was about $500{ }^{\circ} \mathrm{C}$. The bottom parts of concrete interjoists fall down (Fig. 9). 

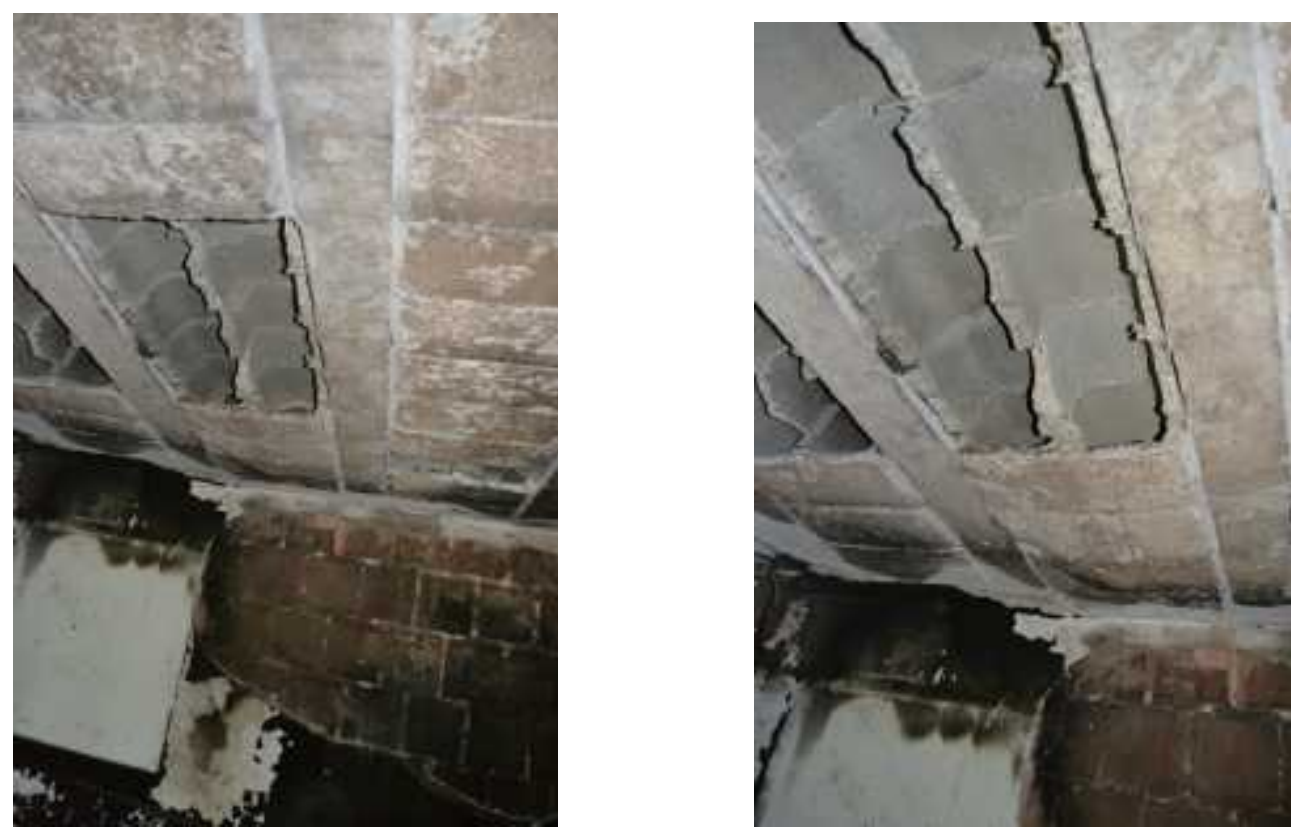

Fig. 8 The fire damaged girder-slab with concrete interjoists
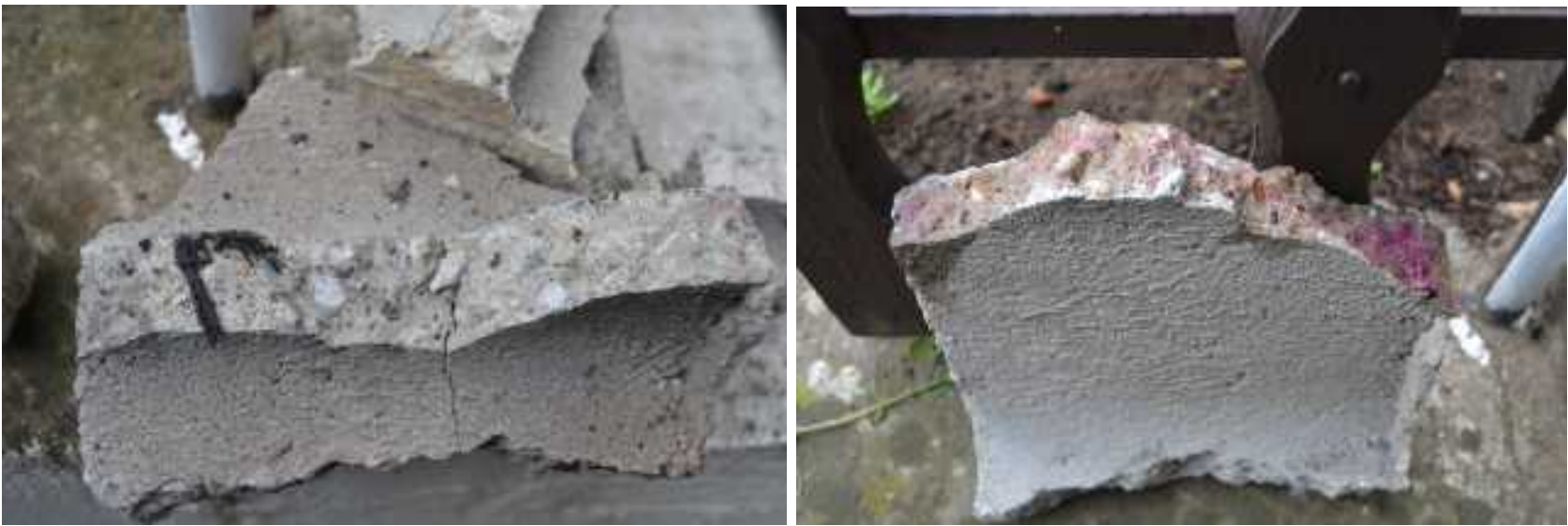

Fig 9. The fire damaged concrete interjoists

\subsection{Brick interjoist}

A family house went up in flames on 13. July 2013. The slab consisted of pretensioned E type girders and brick interjoists (Fig. 10). The axis-distance of $\mathrm{E}$ type girders were $25 \mathrm{~cm}$. The type of girders were E7-48. The height of interjoists were $25 \mathrm{~cm}$. The type of interjoists were FB 60 . The span of girders were $4.8 \mathrm{~m}$ or $5.40 \mathrm{~m}$.

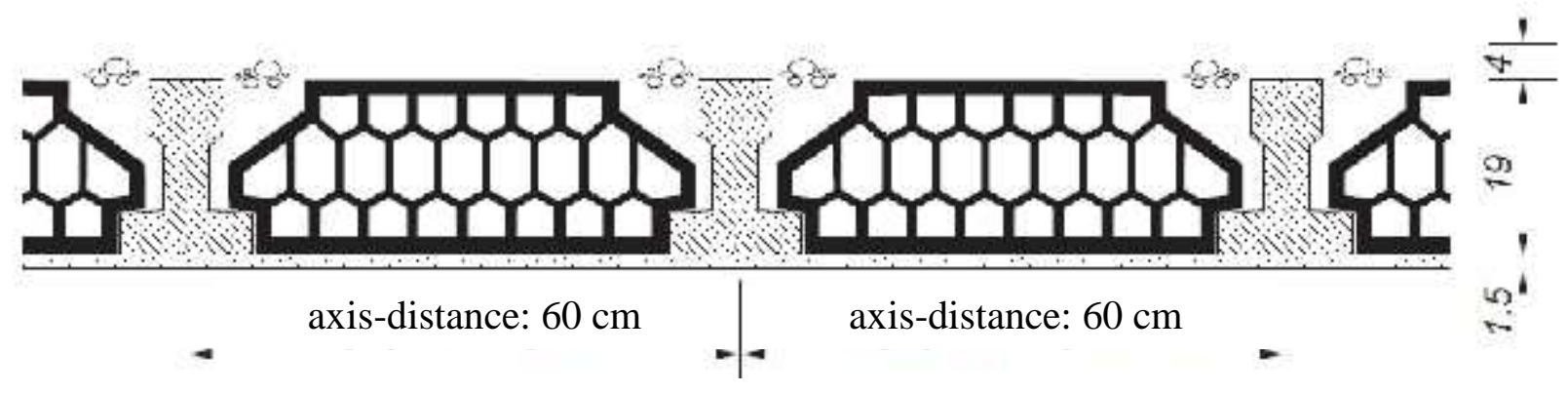

Fig. 10 The girder-slab system with brick interjoists (http://down.archicentrum.hu) 
Due to the fire the slab were damaged (Fig. 11). The concrete cover of the pretensioned E type girders were spalled. The concrete were white-coloured and strongly cracked indicating that the temperature reached about $800{ }^{\circ} \mathrm{C}$. The bottom parts of brick interjoints fall down (Fig. 11).
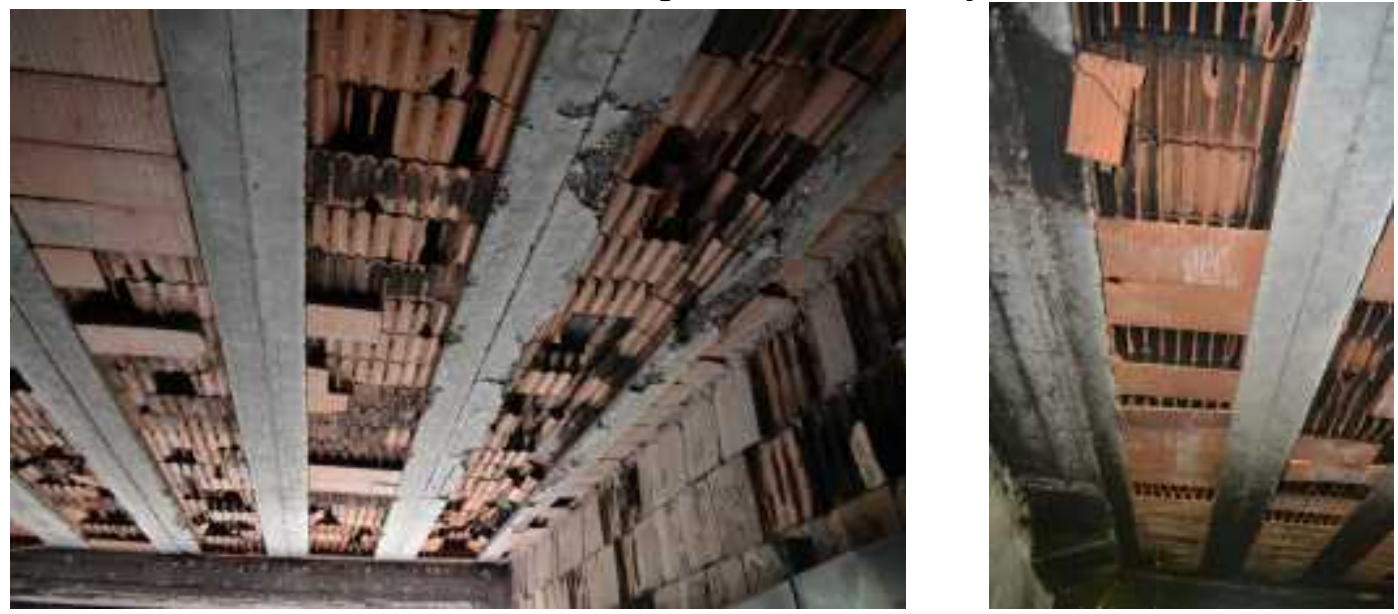

Fig. 11 The fire damaged girder-slab with brick interjoists

\section{CONCLUSIONS}

Spalling of concrete is a complex phenomenon. Full-scale testing in large furnace under the standard fire is costly but it shows the real behaviour of the structures. The first part of this paper presents a method to carry out spalling test in full-scale specimens with exposure to rapid temperature rise using a commonly available furnace in the testing laboratories.

Beam No. 1 (made with the reference concrete without pp fibres) failed in 12 minutes because of the total destruction of the web, due to concrete spalling. Beam No. 2 (made with a mix containing $1 \mathrm{~kg} / \mathrm{m}^{3}$ of pp fibres) failed in 42 minutes in shear (no concrete spalling in the web). Last but not least, Beam No. 3 (made with $1 \mathrm{~kg} / \mathrm{m}^{3}$ of pp fibres and slag-based filler) failed in 71 minutes again in shear as Beam No. 2 and again without concrete spalling in the web).

Summing up, by suitably modifying concrete mix design at no cost or with a rather limited extra cost, considerable increases can be obtained in structural fire resistance, something well known, but still not totally understood by designers and contractors. Nvertheless, fire resistance would come at no or rather limited extra cost, should suitable measures be adopted since the initial phases of the design.

Second part of our study was to summarize the result of real fire cases for a girder-slab systems with concrete or brick interjoists. We observed that due to fire the bottom part of interjoints fall down.

\section{REFERENCES}

Annerel E. and Taerwe L., 2009 Load bearing capacity of precast concrete elements after fire. Proceeding of the 1st International Workshop on Concrete Spalling due to Fire Exposure, eds. Frank Dehn and Eduardus A.B. Koenders, Leipzig (Germany),Sept 3-5, pp.41-51

Balázs L. Gy., Lublóy É., Mezei S., 2010 Thin webbed girder in fire. In: CCC2010. Marianske Lazne, Csehország, 2010.09.30-2010.10.01. Marianske Lazne: pp. 25-33. ISBN: 978-80-87158-26-5

Fellinger J. H. H., 2004 "hear Anchorage Behaviour of Fire Exposed Hollow Core Slabs, PhD Dissertation, Delft University of Technology, Delft (The Netherlands), $261 \mathrm{pp}$.

http://dutker.hu/s_!prods/i_fodemszerkezet_35/i_ferrobeton_e7_feszitett_gerenda_627/t_Ferrobeton\%20E7\% 20fesz\%C3\%ADtett\%20gerenda\%20-\%20F\%C5\%91d\%C3\%A9mszerkezet/index.html\#prettyPhoto/0/

http://down.archicentrum.hu/36/utmutatok/doc/koros_falazoelemek_alk.pdf?f_[cegid]=36 